\title{
Effects of Stoichiometry on the $\mathrm{H}_{2}$-Storage Properties of $\mathrm{Mg}\left(\mathrm{NH}_{2}\right)_{2}-\mathrm{LiH}-\mathrm{LiBH}_{4}$ Tri-Component Systems
}

\author{
Han Wang, ${ }^{[a, b]}$ Hujun Cao, ${ }^{[c]}$ Claudio Pistidda, ${ }^{[c]}$ Sebastiano Garroni, ${ }^{[d, ~ e] ~ G u o t a o ~ W u, ~}{ }^{*[a]}$ \\ Thomas Klassen, ${ }^{[c]}$ Martin Dorheim, ${ }^{[c]}$ and Ping Chen ${ }^{*[a, b]}$
}

\begin{abstract}
The hydrogen desorption pathways and storage properties of $2 \mathrm{Mg}\left(\mathrm{NH}_{2}\right)_{2}-3 \mathrm{LiH}-x \mathrm{LiBH}_{4}$ samples $(x=0,1,2$, and 4 ) were investigated systematically by a combination of pressure composition isotherm $(\mathrm{PCl})$, differential scanning calorimetric (DSC), and volumetric release methods. Experimental results showed that the desorption peak temperatures of $2 \mathrm{Mg}\left(\mathrm{NH}_{2}\right)_{2}-3 \mathrm{LiH}-x \mathrm{LiBH}_{4}$ samples were approximately $10-15^{\circ} \mathrm{C}$ lower than that of $2 \mathrm{Mg}\left(\mathrm{NH}_{2}\right)_{2}-3 \mathrm{LiH}$. The $2 \mathrm{Mg}\left(\mathrm{NH}_{2}\right)_{2}-3 \mathrm{LiH}-4 \mathrm{LiBH}_{4}$ composite in particular began to release hydrogen at $90^{\circ} \mathrm{C}$, thereby exhibiting superior dehydrogenation performance. All of the $\mathrm{LiBH}_{4}$-doped samples could be fully dehydrogenated and re-hydrogenated at
\end{abstract}

a temperature of $143^{\circ} \mathrm{C}$. The high hydrogen pressure region (above 50 bar) of $\mathrm{PCl}$ curves for the $\mathrm{LiBH}_{4}$-doped samples rose as the amount of $\mathrm{LiBH}_{4}$ increased. $\mathrm{LiBH}_{4}$ changed the desorption pathway of the $2 \mathrm{Mg}\left(\mathrm{NH}_{2}\right)_{2}-3 \mathrm{LiH}$ sample under a hydrogen pressure of 50 bar, thereby resulting in the formation of $\mathrm{MgNH}$ and molten $\left[\mathrm{LiNH}_{2}-2 \mathrm{LiBH}_{4}\right]$. That is different from the dehydrogenation pathway of $2 \mathrm{Mg}\left(\mathrm{NH}_{2}\right)_{2}-3 \mathrm{LiH}$ sample without $\mathrm{LiBH}_{4}$, which formed $\mathrm{Li}_{2} \mathrm{Mg}_{2} \mathrm{~N}_{3} \mathrm{H}_{3}$ and $\mathrm{LiNH}_{2}$, as reported previously. In addition, the results of DSC analyses showed that the doped samples exhibited two independent endothermic events, which might be related to two different desorption pathways.

\section{Introduction}

Recently, light-element metal hydrides, borohydrides, alanates, and amides have attracted widespread attention owing to their high volumetric energy densities. ${ }^{[1]}$ However, they are inadequate for onboard applications because of one or more limitations, such as unfavorable thermodynamics, sluggish kinetics, and the release of undesirable byproducts (ammonia or

[a] H. Wang, Prof. G. Wu, Prof. P. Chen

Dalian National Laboratory for Clean Energy

Dalian Institute of Chemical Physics Department

Chinese Academy of Sciences, Dalian 116023 (P. R. China)

E-mail:wgt@dicp.ac.cn pchen@dicp.ac.cn

[b] H. Wang, Prof. P. Chen

University of Chinese Academy of Sciences Beijing 100049 (P. R. China)

[c] Dr. H. Cao, Dr. C. Pistidda, Prof. T. Klassen, Prof. M. Dorheim Institute of Materials Research, Materials Technology Helmholtz-Zentrum Geesthacht Geesthacht 21502 (Germany)

[d] Dr. S. Garroni

International Research Centre in Critical Raw Materials-ICCRAM University of Burgos

Plaza Misael Banuelos s/n, Burgos 09001 (Spain)

[e] Dr. S. Garroni

Consolidated Research Unit UIC-154

Castilla y Leon, Spain

University of Burgos

Hospital del Rey s/n, Burgos 09001 (Spain)

$\square$ Supporting information for this article can be found under: https://doi.org/10.1002/asia.201700287. diborane). ${ }^{[2]}$ To overcome these limitations, a combination of light-element metal hydrides, borohydrides, alanates, and amides as multicomponent systems has been proposed. ${ }^{[2 b]}$ The hydrogen-storage properties of those multicomponent systems are significantly improved relative to single-component (i.e., $\mathrm{LiNH}_{2}$ and $\mathrm{LiH}$ ) systems. The $\mathrm{LiNH}_{2}-\mathrm{LiH}$ system can reversibly store approximately $6.5 \mathrm{wt} \%$ of hydrogen by means of Reaction (1).

$\mathrm{LiNH}_{2}+\mathrm{LiH} \leftrightarrow \mathrm{Li}_{2} \mathrm{NH}+\mathrm{H}_{2}$

In comparison with single-component systems, the $\mathrm{LiNH}_{2}-\mathrm{LiH}$ system exhibits improved thermodynamic properties, released hydrogen purity, and reversibility. However, some problems still exist that hinder the $\mathrm{LiNH}_{2}-\mathrm{LiH}$ system from being suitable for $\mathrm{H}_{2}$-storage applications. For example, the operating temperature at 1.0 bar $\mathrm{H}_{2}$ pressure is above $250^{\circ} \mathrm{C}$. Further amidebased systems were proposed that might replace the $\mathrm{LiNH}_{2}$ with $\mathrm{Mg}\left(\mathrm{NH}_{2}\right)_{2}$ or the $\mathrm{LiH}$ with $\mathrm{MgH}_{2}$ in $\mathrm{LiNH}_{2}-\mathrm{LiH}, \mathrm{Mg}\left(\mathrm{NH}_{2}\right)_{2}-$ $2 \mathrm{LiH}$, or $2 \mathrm{LiNH}_{2}-\mathrm{MgH}_{2}$. Relative to the $\mathrm{LiNH}_{2}-\mathrm{LiH}$ system, $\mathrm{Mg}\left(\mathrm{NH}_{2}\right)_{2}-2 \mathrm{LiH}\left(2 \mathrm{LiNH}_{2}-\mathrm{MgH}_{2}\right)$ possesses some more attractive features, such as the approximately $5.5 \mathrm{wt} \%$ of reversible hydrogen obtainable at $200^{\circ} \mathrm{C}$. For this system, an operating temperature as low as $90^{\circ} \mathrm{C}$ at 1 bar of $\mathrm{H}_{2}$ pressure is thermodynamically expected. This reaction is described by Reaction (2).

$2 \mathrm{LiNH}_{2}+\mathrm{MgH}_{2} \rightarrow \mathrm{Li}_{2} \mathrm{Mg}(\mathrm{NH})_{2}+2 \mathrm{H}_{2} \leftrightarrow \mathrm{Mg}\left(\mathrm{NH}_{2}\right)_{2}+2 \mathrm{LiH}$ 
Unfortunately, owing to the huge kinetic barriers, the rate of dehydrogenation of this composite is relatively low at temperatures below $180^{\circ} \mathrm{C}^{[3]}$ These kinetic barriers are likely to affect the interface reaction between $\mathrm{Mg}\left(\mathrm{NH}_{2}\right)_{2}$ and $2 \mathrm{LiH}$. Although the newly developed ball-milling process assisted by dielectricbarrier discharge plasma influences both the kinetic and thermodynamic properties of hydrogen-storage materials, the introduction of additives seems to be more effective in changing the hydrogen-storage properties and the reaction mechanisms of the $\mathrm{Mg}\left(\mathrm{NH}_{2}\right)_{2}-\mathrm{LiH}$ composite. ${ }^{[4]}$ The addition of $\mathrm{KH}$ to the $\mathrm{Mg}\left(\mathrm{NH}_{2}\right)_{2}-2 \mathrm{LiH}$ system has been reported to significantly lower the desorption temperature owing to the formation of three new K-containing intermediates: $\mathrm{KH}, \mathrm{K}_{2} \mathrm{Mg}\left(\mathrm{NH}_{2}\right)_{4}$, and $\mathrm{Li}_{3} \mathrm{~K}\left(\mathrm{NH}_{2}\right)_{4}$. For the $\mathrm{KH}$-doped material, the lowest operating temperature at which it was possible to fully recharge the material was $107^{\circ} \mathrm{C}^{[5]}$ In 2008 , a three-component composite based on $2 \mathrm{LiNH}_{2}-\mathrm{MgH}_{2}-\mathrm{LiBH}_{4}$ was synthesized and characterized. It exhibited faster kinetics and lower desorption temperatures than those of the binary composites. ${ }^{[6]}$ The ternary system released hydrogen rapidly at $150^{\circ} \mathrm{C}$, which is $50-200^{\circ} \mathrm{C}$ lower than those of the binary composites $2 \mathrm{LiNH}_{2}-\mathrm{LiBH}_{4}$, $\mathrm{LiBH}_{4}-\mathrm{MgH}_{2}$, and $2 \mathrm{LiNH}_{2}-\mathrm{MgH}_{2}$. The proposed reaction mechanism involves the reaction of $\mathrm{LiNH}_{2}$ with $\mathrm{LiBH}_{4}$ to form $\mathrm{Li}_{4} \mathrm{BN}_{3} \mathrm{H}_{10}$ during ball milling and/or upon heating; then almost at the same time $\mathrm{Li}_{4} \mathrm{BN}_{3} \mathrm{H}_{10}$ and $\mathrm{MgH}_{2}$ partially convert to $\mathrm{Mg}\left(\mathrm{NH}_{2}\right)_{2}, \mathrm{LiH}$, and $\mathrm{LiBH}_{4}$. It was supposed that $\mathrm{Li}_{4} \mathrm{BN}_{3} \mathrm{H}_{10}$ and melted $\mathrm{LiNH}_{2}-x \mathrm{LiBH}_{4}$ would be good Li-ion conductors, which might accelerate the transport of substances and improve the dehydrogenation kinetics of $\mathrm{Li}_{4} \mathrm{BN}_{3} \mathrm{H}_{10}-\mathrm{MgH}_{2}$ and/or $\mathrm{Mg}\left(\mathrm{NH}_{2}\right)_{2}-$ $\mathrm{LiH}_{-} \mathrm{iBH}_{4}$ systems. ${ }^{[7]}$ However, the dehydrogenation of $2 \mathrm{LiNH}_{2}-\mathrm{iBH}_{4}-\mathrm{MgH}_{2}$ is reversible only if carried out below $230^{\circ} \mathrm{C}$. At temperatures above $230^{\circ} \mathrm{C}$, the Reactions (3) and (4) might take place, thereby resulting in a change in the dehydrogenation enthalpy from endothermic to mildly exothermic. Owing to the formation of stable desorption product $\mathrm{Li}_{3} B \mathrm{~N}_{2}$, the dehydrogenation process becomes irreversible. ${ }^{[8]}$

$$
\begin{aligned}
& 3 \mathrm{Li}_{2} \mathrm{Mg}(\mathrm{NH})_{2}+2 \mathrm{LiBH}_{4} \rightarrow \mathrm{Li}_{3} \mathrm{BN}_{2}+\mathrm{Mg}_{3} \mathrm{~N}_{2}+2 \mathrm{LiH}+6 \mathrm{H}_{2} \\
& \mathrm{Li}_{3} \mathrm{BN}_{2}+\mathrm{Mg}_{3} \mathrm{~N}_{2}+\mathrm{LiBH}_{4} \rightarrow \mathrm{LiMgBN}_{2}+4 \mathrm{LiH}
\end{aligned}
$$

$\mathrm{Hu}$ et al. also discovered that the addition of $\mathrm{LiBH}_{4}$ not only significantly enhanced the kinetics of the $\mathrm{Mg}\left(\mathrm{NH}_{2}\right)_{2}-2 \mathrm{LiH}$ composite but also reduced the hydrogen desorption enthalpy. ${ }^{[9]}$ When $10 \mathrm{~mol} \% \mathrm{LiBH}_{4}$ was added to the $\mathrm{Mg}\left(\mathrm{NH}_{2}\right)_{2}-2 \mathrm{LiH}$ composite, $5 \mathrm{wt} \%$ of hydrogen could be reversibly desorbed at $140^{\circ} \mathrm{C}$ and reabsorbed at $100^{\circ} \mathrm{C}$; and the desorption enthalpy was reduced from approximately 44 to $36.5 \mathrm{~kJ} \mathrm{~mol}^{-1} \mathrm{H}_{2} \cdot{ }^{[0]} \mathrm{Fol}-$ lowing these studies, other borohydrides such as $\mathrm{Ca}\left(\mathrm{BH}_{4}\right)_{2}$ and $\mathrm{Mg}\left(\mathrm{BH}_{4}\right)_{2}$ were also investigated; ${ }^{[11]}$ they showed similar effects to $\mathrm{LiBH}_{4}$ because metathesis reactions take place between $\mathrm{Ca}\left(\mathrm{BH}_{4}\right)_{2} / \mathrm{Mg}\left(\mathrm{BH}_{4}\right)_{2}$ and $\mathrm{LiH}$ to form $\mathrm{LiBH}_{4}$ and $\mathrm{CaH}_{2} / \mathrm{MgH}_{2}$ during ball milling or upon heat treatment.

The previous investigations focused mainly on the molar ratio of $\mathrm{Mg} / \mathrm{Li}$ (1:2) to lower the hydrogen-desorption temperature and suppress the release of ammonia in the $\mathrm{Mg}\left(\mathrm{NH}_{2}\right)_{2}-$ $2 \mathrm{LiH}$ and $2 \mathrm{LiNH}_{2}-\mathrm{MgH}_{2}$ systems. The desorption reaction of
$\mathrm{Mg}\left(\mathrm{NH}_{2}\right)_{2}-2 \mathrm{LiH}$ during pressure composition isotherm (PCI) measurement $\left(250^{\circ} \mathrm{C}\right)$ involves two main steps, and the optimal proportion of $\mathrm{Mg}\left(\mathrm{NH}_{2}\right)_{2}$ and $\mathrm{LiH}$ was determined to be 2 to 3 , as depicted in Reaction (5). ${ }^{[12]}$

$2 \mathrm{Mg}\left(\mathrm{NH}_{2}\right)_{2}+3 \mathrm{LiH} \AA \mathrm{Li}_{2} \mathrm{Mg}_{2}(\mathrm{NH})_{3}+\mathrm{LiNH}_{2}+3 \mathrm{H}_{2}$

When introducing $\mathrm{Lil}, \mathrm{LiBr}$, and $\mathrm{LiBH}_{4}$ into the $2 \mathrm{Mg}\left(\mathrm{NH}_{2}\right)_{2}-3 \mathrm{LiH}$ system, the reaction enthalpy of the $2 \mathrm{Mg}\left(\mathrm{NH}_{2}\right)_{2}-3 \mathrm{LiH}$ system decreases to $33.3,31.9$, and $35.8 \mathrm{~kJ} \mathrm{~mol}^{-1} \mathrm{H}_{2}$, respectively. The thermodynamic improvement is due to the formation of more stable products, that is, $\mathrm{Li}_{3}\left(\mathrm{NH}_{2}\right)_{2} \mathrm{l}, \mathrm{Li}_{2} \mathrm{NH}_{2} \mathrm{Br}$, and $\mathrm{Li}_{4} \mathrm{BN}_{3} \mathrm{H}_{10}$. Furthermore, an additional high-pressure sloping region is observed in the $\mathrm{PCl}$ dehydrogenation of $2 \mathrm{LiNH}_{2}-\mathrm{MgH}_{2}-\mathrm{LiBH}_{4}$ and $2 \mathrm{Mg}\left(\mathrm{NH}_{2}\right)_{2}-3 \mathrm{LiH}-1 / 3 \mathrm{LiBH}_{4}{ }^{[13]}$ In our early work, the $\mathrm{PCl}$ curve of the $2 \mathrm{Mg}\left(\mathrm{NH}_{2}\right)_{2}-3 \mathrm{LiH}-4 \mathrm{LiBH}_{4}$ composite showed an extended high-pressure region with a dehydrogenation enthalpy of $24 \mathrm{~kJ} \mathrm{~mol}^{-1} \mathrm{H}_{2}$. Reversible $\mathrm{H}_{2}$ absorption and desorption from $2 \mathrm{Mg}\left(\mathrm{NH}_{2}\right)_{2}-3 \mathrm{LiH}-4 \mathrm{LiBH}_{4}$ was achieved at 53 and $98^{\circ} \mathrm{C}$, respectively. A better reaction pathway is involved in the high-pressure region. $\mathrm{LiBH}_{4}$ exhibits solvent-like behavior that considerably stabilizes the dehydrogenation intermediates and products and thus changes the thermodynamics and kinetics of dehydrogenation and re-hydrogenation. ${ }^{[14]}$

The stoichiometry of the $\mathrm{Mg}\left(\mathrm{NH}_{2}\right)_{2}-\mathrm{LiH}-\mathrm{LiBH}_{4}$ composites might have significant influence on both the thermodynamic and kinetic properties, similar to that of other hydrogen-storage alloys. ${ }^{[15]}$ In this work, $\mathrm{Mg}\left(\mathrm{NH}_{2}\right)_{2}-\mathrm{LiH}-\mathrm{LiBH}_{4}$ systems in molar ratios of 2:3:1, 2:3:2, and 2:3:4 were systematically investigated. The dehydrogenation behaviors of the $2 \mathrm{Mg}\left(\mathrm{NH}_{2}\right)_{2}-$ $3 \mathrm{LiH}-x \mathrm{LiBH}_{4}$ composites were studied by means of $\mathrm{PCl}$ and volumetric release measurements. A novel desorption pathway to form $\mathrm{MgNH}$ and an eutectic melting solution of $\mathrm{LiBH}_{4}$ and $\mathrm{LiNH}_{2}$ with a molar ratio of $1: 2$ at elevated temperatures is then proposed.

\section{Results and Discussion}

\section{Kinetic Behavior}

Four samples, namely, $2 \mathrm{Mg}\left(\mathrm{NH}_{2}\right)_{2}-3 \mathrm{LiH}-x \mathrm{LiBH}_{4}$ with $x=0.5$, 1, 2 , and 4 , were prepared for investigation with temperatureprogrammed desorption mass spectrometry (TPD-MS) (Figure 1). For comparison, the TPD-MS curve of the pristine $2 \mathrm{Mg}\left(\mathrm{NH}_{2}\right)_{2}-3 \mathrm{LiH}$ sample is also presented. TPD measurements revealed that the dehydrogenation onset temperature of the 2:3:4 sample is the lowest among the investigated systems, and its peak temperature is $15^{\circ} \mathrm{C}$ lower than that of the pristine sample $\left(189^{\circ} \mathrm{C}\right.$; Figure $\left.1 \mathrm{a}\right)$.

The TPD curve of the 2:3:4 sample is different from the others. It presents a weak desorption peak at $135^{\circ} \mathrm{C}$, a main dehydrogenation peak at $174^{\circ} \mathrm{C}$, and a shoulder peak at $189^{\circ} \mathrm{C}$. TPD curves of the $2: 3: 0.5,2: 3: 1$, as well as $2: 3: 2$ samples are almost the same, since only the main dehydrogenation peaks can be observed. The TPD curves of the 2:3:0.5 and 2:3:1 samples almost overlap with each other, and their peak temperature is $179^{\circ} \mathrm{C}$. Compared to the pristine sample, all of 


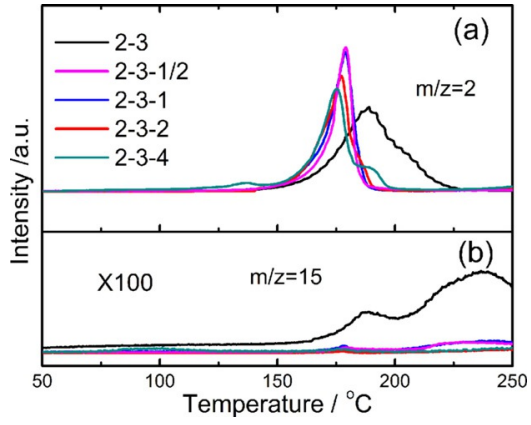

Figure 1. TPD-MS curves of $2 \mathrm{Mg}\left(\mathrm{NH}_{2}\right)_{2}-3 \mathrm{LiH}-x \mathrm{LiBH}_{4}$ mixtures $(x=0,0.5,1,2$ and 4 ; based on the ratio of $\mathrm{Mg}\left(\mathrm{NH}_{2}\right)_{2} / \mathrm{LiH} / \mathrm{LiBH}_{4}$, they are also denoted as $2: 3,2: 3: 0.5,2: 3: 1,2: 3: 2$, and $2: 3: 4)$. Samples heated from 50 to $250{ }^{\circ} \mathrm{C}$ at a heating rate of $2{ }^{\circ} \mathrm{Cmin}^{-1}$.

the $\mathrm{LiBH}_{4}$-doped samples not only desorb hydrogen over narrower temperature ranges but also have a descending trend in their onset and peak temperatures. Moreover, the amount of ammonia released from $\mathrm{LiBH}_{4}$-doped samples is much lower than that of the pristine sample, and it only can be observed above $210^{\circ} \mathrm{C}$ for the 2:3:0.5 and 2:3:1 samples, which reveals that the addition of $\mathrm{LiBH}_{4}$ effectively suppresses the evolution of this undesired side product (Figure 1b).

The dehydrogenation activation energies $\left(E_{\mathrm{a}}\right)$ of the $2 \mathrm{Mg}\left(\mathrm{NH}_{2}\right)_{2}-3 \mathrm{LiH}-x \mathrm{LiBH}_{4}$ and the pristine systems were calculated by means of Kissinger's method [Eq. (6)]:

$\ln \left(\beta / T_{\mathrm{m}}{ }^{2}\right)=-E_{\mathrm{a}} /\left(R T_{\mathrm{m}}\right)+\mathrm{C}$

Here, $T_{m}$ is the peak temperature at which the maximum reaction rate is attained, $\beta$ the heating rate, $E_{\mathrm{a}}$ the activation energy, and $R$ the gas constant. The TPD method was applied to collect the maximum reaction rate temperatures at various heating rates (Figure 2). As shown in Figure 2a, a good linear dependency of $\ln \left(\beta / T_{\mathrm{m}}{ }^{2}\right)$ upon $1 / T_{\mathrm{m}}$ exists for both samples. The slope of the fitted line is used to determine the value of $E_{\mathrm{a}} / R$. The dehydrogenation activation energies of the $2 \mathrm{Mg}\left(\mathrm{NH}_{2}\right)_{2}-3 \mathrm{LiH}-x \mathrm{LiBH}_{4}$ samples dropped from 109 to $76 \mathrm{~kJ} \mathrm{~mol}^{-1}$, respectively (Table 1), when the amount of $\mathrm{LiBH}_{4}$ in the $2 \mathrm{Mg}\left(\mathrm{NH}_{2}\right)_{2}-3 \mathrm{LiH}-x \mathrm{LiBH}_{4}$ samples was increased from 1 to
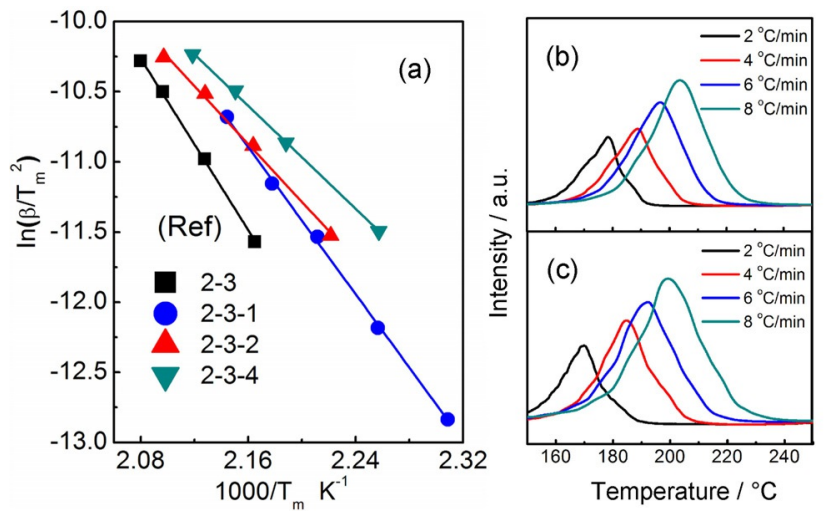

Figure 2. a) Kissinger's plots of samples of 2:3, 2:3:1, 2:3:2, 2:3:4. $\mathrm{H}_{2}$-TPD profiles collected at different ramping rates for b) 2:3:2 and c) 2:3:4 samples.

\begin{tabular}{|c|c|c|c|}
\hline Composite & $2: 3: 1$ & $2: 3: 2$ & $2: 3: 4$ \\
\hline$R$-squared & 0.999 & 0.995 & 0.999 \\
\hline$E_{\mathrm{a}}\left[\mathrm{kJ} \mathrm{mol}^{-1}\right]$ & $109 \pm 4.0$ & $86 \pm 5.3$ & $76 \pm 3.5$ \\
\hline
\end{tabular}

4. This result indicates that the addition of $\mathrm{LiBH}_{4}$ can effectively reduce the activation energy of the $2 \mathrm{Mg}\left(\mathrm{NH}_{2}\right)_{2}-3 \mathrm{LiH}$ composite $\left(127 \mathrm{~kJ} \mathrm{~mol}^{-1}\right)$, which agrees well with the prior results. ${ }^{[16]}$

To further investigate the differences between the 2:3:1 and 2:3:4 samples, thermogravimetric/differential thermal analysis (TG-DTA) experiments were carried out (Figure 3). The desorp-

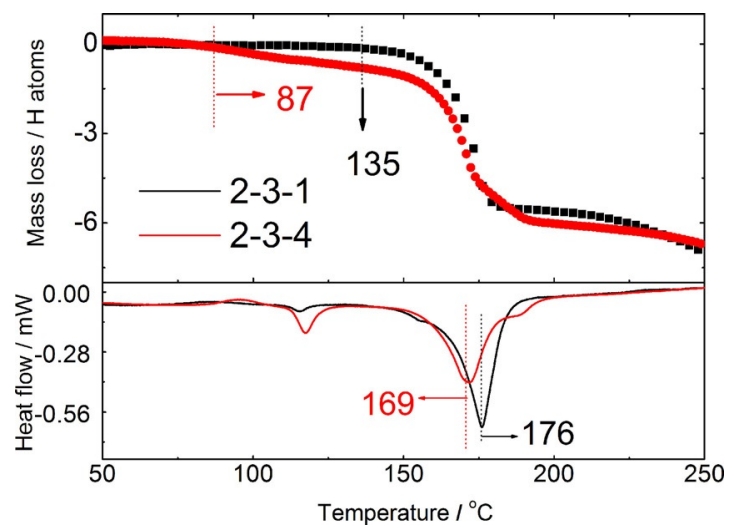

Figure 3. TG-DTA curves of samples of $2: 3: 1$ and 2:3:4. Samples heated from 50 to $250^{\circ} \mathrm{C}$ with a ramping rate of $2^{\circ} \mathrm{Cmin}^{-1}$.

tion process of the $2: 3: 4$ sample started at $87^{\circ} \mathrm{C}$, which is $48^{\circ} \mathrm{C}$ lower than that of the 2:3:1 sample. After heating to $200^{\circ} \mathrm{C}$, weight losses of 3.5 and $2.7 \%$ were found for 2:3:1 and 2:3:4 samples, respectively. Two endothermic signals can be observed in both cases. The first endothermic event relates to the low/high temperature transition phase of $\mathrm{LiBH}_{4}$. As the amount of $\mathrm{LiBH}_{4}$ increases, this signal clearly becomes stronger. Apart from the phase transform event of $\mathrm{LiBH}_{4}$, only a single endothermic event at $176^{\circ} \mathrm{C}$ is visible. This means that the dehydrogenation process of the 2:3:1 sample is a one-step reaction as described in a previous publication. ${ }^{[17]}$ Similar to the TPD-MS results, a shoulder peak can also be observed along with the major dehydrogenation peak in the DTA curve of the 2:3:4 sample, which also indicates that the desorption pathway of the 2:3:4 sample might be different.

Isothermal $\left(143^{\circ} \mathrm{C}\right)$ dehydrogenation/re-hydrogenation measurements were carried out for the $2 \mathrm{Mg}\left(\mathrm{NH}_{2}\right)_{2}-3 \mathrm{LiH}-$ $x \mathrm{LiBH}_{4}(x=0,1,2,4)$ samples using a volumetric apparatus; the normalized data (hydrogen atoms $/ 2 \mathrm{Mg}\left(\mathrm{NH}_{2}\right)_{2}-3 \mathrm{LiH}$ ) are reported in Figure 4. The $2 \mathrm{Mg}\left(\mathrm{NH}_{2}\right)_{2}-3 \mathrm{LiH}$ sample released 3.5 hydrogen atoms at $143^{\circ} \mathrm{C}$ after 250 minutes, which is significantly lower than the theoretical value (six atoms). However, the dehydrogenation kinetics of the $2 \mathrm{Mg}\left(\mathrm{NH}_{2}\right)_{2}-3 \mathrm{LiH}-x \mathrm{LiBH}_{4}$ samples were significantly improved by the addition of $\mathrm{LiBH}_{4}$, and a two-stage dehydrogenation process can be observed. For all 

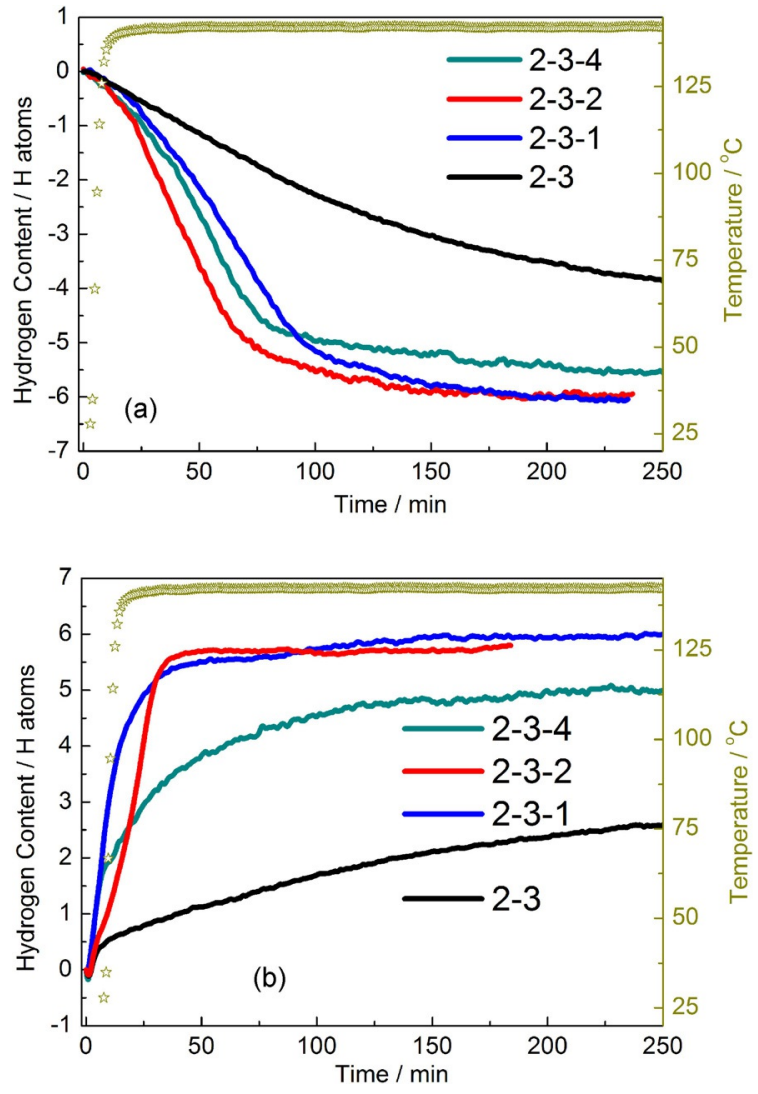

Figure 4. Volumetric isotherm at $143{ }^{\circ} \mathrm{C}$ a) dehydrogenation and b) re-hydrogenation curves of 2:3, 2:3:1, 2:3:2, and 2:3:4 under the $\mathrm{H}_{2}$ backpressure of 0 and 60 bar for dehydrogenation and re-hydrogenation, respectively.

the investigated materials, the evolution of hydrogen rapidly reached $80 \%$ of the theoretical $\mathrm{H}_{2}$ capacities and was complete after about 90,70 , and 170 min for the 2:3:1, 2:3:2, and 2:3:4 samples, respectively. The 2:3:2 sample exhibited the fastest desorption rate compared to the others. It should be pointed out that the dehydrogenation kinetics do not linearly follow the doping ratio of $\mathrm{LiBH}_{4}$. The tangent slopes of the initial linear parts indicate that the dehydrogenation rate of the 2:3:2 sample is approximately 2.5 times faster than the pristine sample.

Unlike the isothermal dehydrogenation results, the isothermal absorption results show that the 2:3:1 sample had the fastest absorption rate, and it needed only 25 minutes to absorb more than $80 \%$ of the total hydrogen content. However, only $12 \%$ of hydrogen was absorbed by the $2: 3$ sample within the same time. During the first ten minutes, the 2:3:1 and 2:3:4 samples had the same absorption rates. The absorption rates of the 2:3:4 and 2:3 samples decelerated gradually, whereas the 2:3:1 sample maintained its fast absorption rate. ${ }^{[17]}$

\section{Thermodynamic Properties}

For all the investigated systems the dehydrogenation properties were investigated by means of $\mathrm{PCl}$ methods at $187^{\circ} \mathrm{C}$ (Figure 5). Figure $5 \mathrm{a}$ shows that the $2 \mathrm{Mg}\left(\mathrm{NH}_{2}\right)_{2}-3 \mathrm{LiH}$ sample
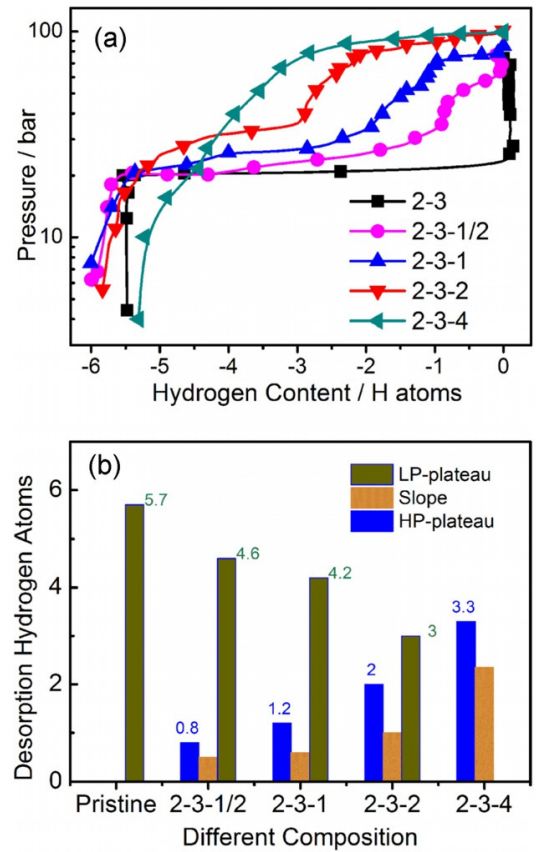

Figure 5. a) Pressure-composition isotherm (PCI) curves of samples of 2:3, 2:3:1, 2:3:2, and $2: 3: 4$ at a temperature of $187^{\circ} \mathrm{C}$ under $\mathrm{H}_{2}$ backpressure dropped from 100 to 1 bar. b) Detailed analysis of the $\mathrm{PCl}$ results.

could only release hydrogen at or under 20 bar. $^{[12,18]}$ In contrast to the $2 \mathrm{Mg}\left(\mathrm{NH}_{2}\right)_{2}-3 \mathrm{LiH}$ sample, the $2 \mathrm{Mg}\left(\mathrm{NH}_{2}\right)_{2}-3 \mathrm{LiH}-x \mathrm{LiBH}_{4}$ samples started to release hydrogen at much higher $\mathrm{H}_{2}$ pressures. As an example, the 2:3:4 sample released hydrogen at 100 bar of $\mathrm{H}_{2}$ pressure. In checking these $\mathrm{PCl}$ curves carefully, they can be divided into three parts: a high-pressure plateau, a sloped region, and a low-pressure plateau. For the 2:3:4 sample, only the desorption slope and the high-pressure plateau are clearly visible. The different ratios of $\mathrm{LiBH}_{4}$ lead to different amounts of $\mathrm{H}_{2}$ being released in the slope segment of the $\mathrm{PCl}$ measurement as well as to different starting pressures. From Figure $5 \mathrm{a}$, it can be observed that, during the release of the first hydrogen atom, the equilibrium pressures were 97, 89, 70,40 , and 20 bar for the 2:3:4, 2:3:2, 2:3:1, 2:3:0.5, and 2:3 samples, respectively. The dehydrogenation capacities (atoms) during the different steps are summarized in Figure 5b. It is clear that at high pressure it is possible to release more hydrogen in the high-pressure plateau region when increasing the amount of $\mathrm{LiBH}_{4}$, whereas the amount of hydrogen released in the low-pressure (LP) plateau region gradually decreases or even disappears when the molar ratio of $\mathrm{LiBH}_{4}$ is increased to 4 .

In addition, $2 \mathrm{Mg}\left(\mathrm{NH}_{2}\right)_{2}-3 \mathrm{LiH}-x \mathrm{LiBH}_{4}$ samples $(x=0,1,2,4)$ were heated from room temperature to $200^{\circ} \mathrm{C}$ under $\mathrm{H}_{2}$ pressure at 50 bar (Figure 6). The $2 \mathrm{Mg}\left(\mathrm{NH}_{2}\right)_{2}-3 \mathrm{LiH}$ sample could not release hydrogen at this temperature and pressure; interestingly, all the other samples could release hydrogen at a temperature of $140^{\circ} \mathrm{C}$ under the sample hydrogen pressure, and the dehydrogenation content increased as the molar ratio of $\mathrm{LiBH}_{4}$ in the $2 \mathrm{Mg}\left(\mathrm{NH}_{2}\right)_{2}-3 \mathrm{LiH}-x \mathrm{LiBH}_{4}$ sample increased. Finally, 3.6, 2.5, and 1.4 hydrogen atoms were released from the 2:3:4, 2:3:2, and 2:3:1 samples, respectively. 


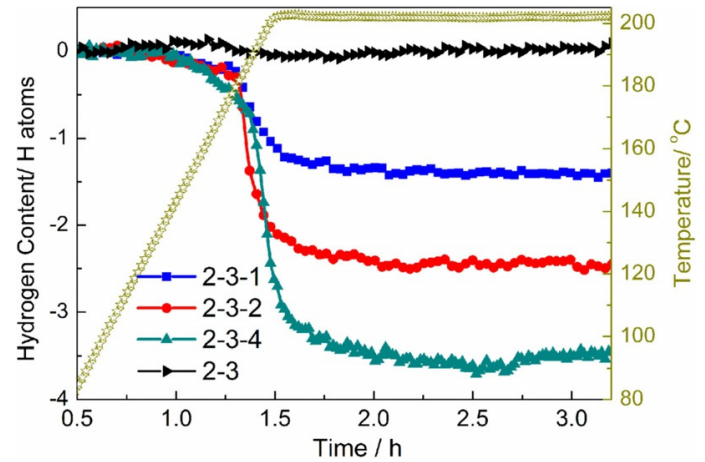

Figure 6. Volumetric release of ternary compositions 2:3, 2:3:1, 2:3:2, and 2:3:4 dehydrogenated upon dynamic heating $\left(2^{\circ} \mathrm{Cmin}^{-1}\right)$ up to $200^{\circ} \mathrm{C}$ with 50 bar of $\mathrm{H}_{2}$ background pressure.

\section{The Role of $\mathrm{LiBH}_{4}$}

To uncover the underlying reason that enables the $2 \mathrm{Mg}\left(\mathrm{NH}_{2}\right)_{2}-$ $3 \mathrm{LiH}-x \mathrm{LiBH}_{4}$ samples to release $\mathrm{H}_{2}$ under a hydrogen background pressure of 50 bar, dehydrogenation products of these samples were studied by means of XRD and FTIR techniques (Figure 7). XRD patterns show the diffraction peaks of
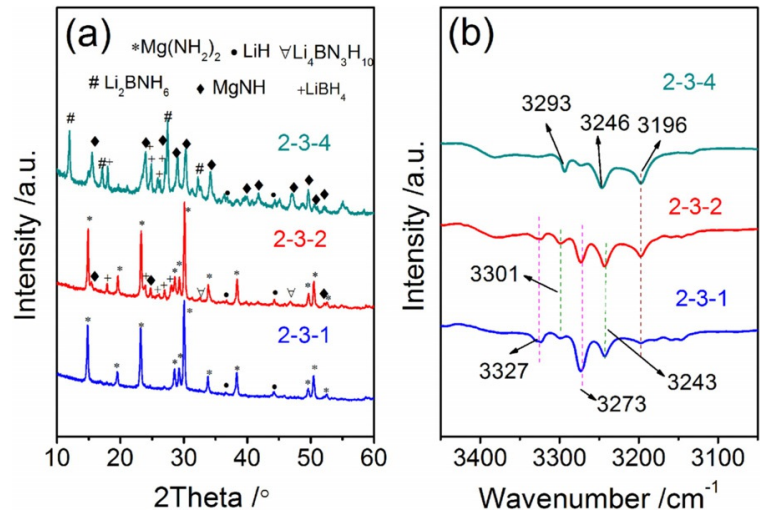

Figure 7. a) XRD patterns and b) FTIR spectrum of 2:3:1, 2:3:2, and 2:3:4 dehydrogenated upon $200^{\circ} \mathrm{C}$ with 50 bar of $\mathrm{H}_{2}$ background pressure.

$\mathrm{Mg}\left(\mathrm{NH}_{2}\right)_{2}$ in the dehydrogenated 2:3:1 and 2:3:2 samples. In addition, several weak diffraction peaks of $\mathrm{MgNH}$ are also visible in the dehydrogenated 2:3:2 sample. Conversely, only the diffraction peaks of $\mathrm{MgNH}$ and $\mathrm{Li}_{2} \mathrm{BNH}_{6}$ are present in the dehydrogenated 2:3:4 sample. It is clear at this point that when the molar ratio of $\mathrm{Mg}\left(\mathrm{NH}_{2}\right)_{2}$ and $\mathrm{LiBH}_{4}$ is higher than two the diffraction peaks of $\mathrm{MgNH}$ are present among the decomposition products. The presence of $\mathrm{MgNH}$, rather than $\mathrm{Li}_{2} \mathrm{Mg}_{2} \mathrm{~N}_{3} \mathrm{H}_{3}$, means that the dehydrogenation pathways of $2 \mathrm{Mg}\left(\mathrm{NH}_{2}\right)_{2}-3 \mathrm{LiH}$ system might be changed. To verify this possibility, the dehydrogenated $2 \mathrm{Mg}\left(\mathrm{NH}_{2}\right)_{2}-3 \mathrm{LiH}-x \mathrm{LiBH}_{4}$ composites were investigated by FTIR spectroscopy (Figure 7b). The FTIR results reveal that $\mathrm{Li}_{2} \mathrm{BNH}_{6} \quad\left(3298 / 3246 \mathrm{~cm}^{-1}\right)^{[17]}$ or $\mathrm{Li}_{4} \mathrm{BN}_{3} \mathrm{H}_{10} \quad$ (3301/ $\left.3243 \mathrm{~cm}^{-1}\right)^{[17]}$ are present during the dehydrogenation process under 50 bar hydrogen pressure. The $\mathrm{N}-\mathrm{H}$ stretching at 3273 and $3327 \mathrm{~cm}^{-1}$ that belongs to $\mathrm{Mg}\left(\mathrm{NH}_{2}\right)_{2}$ gradually decreases, and the $\mathrm{N}-\mathrm{H}$ stretching of $\mathrm{MgNH}$ at $3198 \mathrm{~cm}^{-1}$ emerges upon increasing the amount of $\mathrm{LiBH}_{4}$ in the $2 \mathrm{Mg}\left(\mathrm{NH}_{2}\right)_{2}-3 \mathrm{LiH}-x \mathrm{LiBH}_{4}$ composite ${ }^{[19]}$ This means that $\mathrm{MgNH}$ exists as a product as the dehydrogenation proceeds. As discussed above, it is clear that the addition of $\mathrm{LiBH}_{4}$ changes the dehydrogenation pathway of the $2 \mathrm{Mg}\left(\mathrm{NH}_{2}\right)_{2}-3 \mathrm{LiH}$ sample under the hydrogen pressure of 50 bar, thus yielding the formation of $\mathrm{MgNH}$ and an eutectic that melts at elevated temperatures instead of forming $\mathrm{Li}_{2} \mathrm{Mg}_{2} \mathrm{~N}_{3} \mathrm{H}_{3}$ and $\mathrm{LiNH}_{2}$. This is also confirmed by the disappearance of $\mathrm{LiBH}_{4}$ reflections in the in situ XRD investigation of the 2:3:1 sample collected in a backpressure of hydrogen between 80 and 1 bar (see the Supporting Information). According to the phase diagram of $\mathrm{LiNH}_{2}$ and $\mathrm{LiBH}_{4}$, the eutectic melt might be composed of $\mathrm{LiNH}_{2}$ and $\mathrm{LiBH}_{4}{ }^{\left[{ }^{[7]}\right.} \mathrm{LiNH}_{2}$ and $\mathrm{LiBH}_{4}$ in a molar ratio of $1: 2$ has its lowest melting point at $95^{\circ} \mathrm{C}$, which will be condensed into $\mathrm{Li}_{2} \mathrm{BNH}_{6}, \mathrm{Li}_{4} \mathrm{BN}_{3} \mathrm{H}_{10}$, and $\mathrm{LiBH}_{4}$ when cooled under moderate conditions.

Calorimetric measurements of these samples under a closed system were carried out using a DSC-C80 instrument, and the results are reported in Figure 8 . The pristine sample of

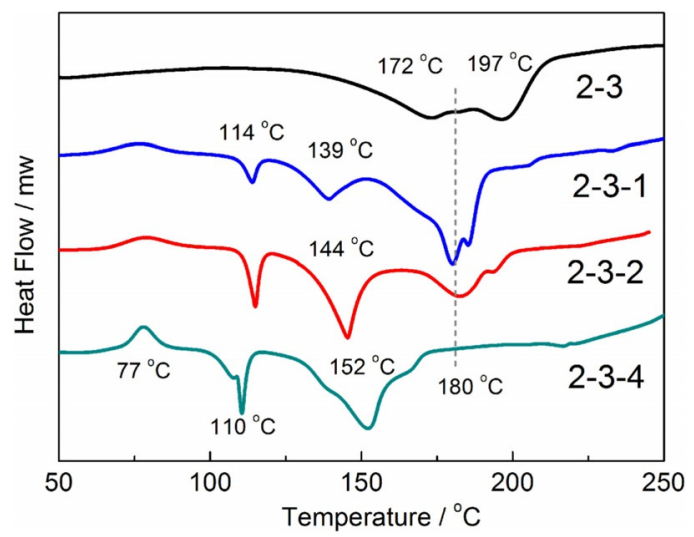

Figure 8. DSC-C80 (closed-system) measurements of ternary compositions $2 \mathrm{Mg}\left(\mathrm{NH}_{2}\right)_{2}-3 \mathrm{LiH}-x \mathrm{LiBH}_{4}(x=0,1,2$, and 4$)$ dehydrogenated upon dynamic heating $\left(0.2^{\circ} \mathrm{C} \mathrm{min}^{-1}\right)$ up to $250^{\circ} \mathrm{C}$ under the 1 bar argon atmosphere.

$2 \mathrm{Mg}\left(\mathrm{NH}_{2}\right)_{2}-3 \mathrm{LiH}$ starts to release hydrogen at about $125^{\circ} \mathrm{C}$ and reaches its main peaks at 172 and $197^{\circ} \mathrm{C}$, as also previously seen in the TPD-MS analysis in Figure 1. Moreover, a clear exothermic peak at $77^{\circ} \mathrm{C}$ is detected in the 2:3:4 sample, which is still under investigation. The endothermic event at approximately $110^{\circ} \mathrm{C}$ can be related to the phase transformation of $\mathrm{LiBH}_{4}$. The following two endothermic events at approximately 139 and $180^{\circ} \mathrm{C}$ are possibly related to two dehydrogenation reactions. With the increase in the $\mathrm{LiBH}_{4}$ component, the low-temperature endothermic peak increases and the hightemperature endothermic peak decreases. The endothermic peak at $180^{\circ} \mathrm{C}$ even disappears in the $2: 3: 4$ sample, and the main endothermic peak moves to $150^{\circ} \mathrm{C}$, which confirms that the dehydrogenation pathway of $2 \mathrm{Mg}\left(\mathrm{NH}_{2}\right)_{2}-3 \mathrm{LiH}$ has completely changed by the addition of $4 \mathrm{~mol} \mathrm{LiBH}_{4}$. 


\section{Conclusion}

The effects of the stoichiometry of $\mathrm{LiBH}_{4}$ in the $2 \mathrm{Mg}\left(\mathrm{NH}_{2}\right)_{2}-$ $3 \mathrm{LiH}-x \mathrm{LiBH}(x=1,2$, and 4$)$ were investigated in detail in this work. Both the onset and peak temperatures were shifted to lower temperature with the help of $\mathrm{LiBH}_{4}$. The $2 \mathrm{Mg}\left(\mathrm{NH}_{2}\right)_{2}-$ $3 \mathrm{LiH}-4 \mathrm{LiBH}_{4}$ sample in particular started to dehydrogenate at approximately $90^{\circ} \mathrm{C}$. The $2 \mathrm{Mg}\left(\mathrm{NH}_{2}\right)_{2}-3 \mathrm{LiH}-x \mathrm{LiBH}_{4}$ composites exhibit significant low-temperature $\left(143^{\circ} \mathrm{C}\right)$ reversibility, and their reversible hydrogen capacities are close to their theoretical value of six hydrogen atoms. The kinetic effect of $\mathrm{LiBH}_{4}$ is also confirmed by their activation energies, which decrease

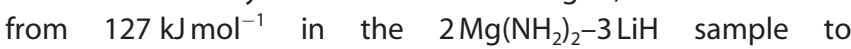
$76 \mathrm{~kJ} \mathrm{~mol}^{-1}$ in the $2 \mathrm{Mg}\left(\mathrm{NH}_{2}\right)_{2}-3 \mathrm{LiH}-4 \mathrm{LiBH}_{4}$ sample. The $\mathrm{PCl}$ curves show a high-pressure plateau, a low-pressure plateau, and a slope in the $\mathrm{LiBH}_{4}$-doped samples, and the length of the high-pressure plateau depends on the amount of $\mathrm{LiBH}_{4}$. Moreover, the alteration of the thermodynamics corresponds to the new reaction pathway; for example, the desorption products of the ternary system of $2 \mathrm{Mg}\left(\mathrm{NH}_{2}\right)_{2}-3 \mathrm{LiH}-4 \mathrm{LiBH}_{4}$ under 50 bar of hydrogen background pressure are an eutectic melting solution of $\left[\mathrm{LiNH}_{2}-2 \mathrm{LiBH}_{4}\right]$ and $\mathrm{MgNH}$, which are completely different from the products of the $2 \mathrm{Mg}\left(\mathrm{NH}_{2}\right)_{2}-3 \mathrm{LiH}$ system.

\section{Experimental Section}

\section{Sample Preparation}

$\mathrm{LiH}$ and $\mathrm{LiBH}_{4}$ were purchased from Alfa-Aesar and Sigma-Aldrich with purities of 98 and $95 \%$, respectively. $\mathrm{Mg}\left(\mathrm{NH}_{2}\right)_{2}$ was a self-synthesized product with a purity of $\geq 95 \%$, and its synthesis procedure was described in a previous publication. ${ }^{[17]}$ The $2 \mathrm{Mg}\left(\mathrm{NH}_{2}\right)_{2}-$ $3 \mathrm{LiH}-x \mathrm{LiBH}_{4}$ mixtures, in which $x=0,0.5,1,2$, and 4 (for convenience, the samples were denoted as 2:3, 2:3:0.5, 2:3:1, 2:3:2, and 2:3:4 according to their $\mathrm{LiBH}_{4}$ content), were ball milled using a Retsch PM400 planetary mill at 200 rpm for 24 hours. The ball-tosample weight ratio was 60:1. To prevent degradation of the material owing to the heat developed during milling, the mill was set to revolve for $2 \mathrm{~min}$ in one direction and pause for $15 \mathrm{~s}$, and then revolve in the opposite direction. To avoid air contamination, all handling of the materials was performed in a MBRAUN glovebox filled with purified argon gas $\left(\mathrm{O}_{2}: \delta<5 \mathrm{ppm} ; \mathrm{H}_{2} \mathrm{O}: \delta<0.1 \mathrm{ppm}\right)$.

\section{Analysis of Hydrogen-Storage properties}

A homemade temperature-programmed desorption (TPD) system coupled with a mass spectrometer (MS) (Hiden QIC-20) was used to check the evolving gases hydrogen $(m / z=2)$ and ammonia $(\mathrm{m} /$ $z=15$ ). In each test, the sample was loaded and heated at a rate of $2{ }^{\circ} \mathrm{C} \mathrm{min}{ }^{-1}$ up to $400^{\circ} \mathrm{C}$. A thermocouple was used to measure the sample temperature by inserting it into the center of samples. Activation energies were calculated by Kissinger's method, and the fastest reaction rates were monitored by TPD techniques.

Thermogravimetry coupled with differential thermal analysis (TGDTA) measurements were conducted using a STA-449C (Netzsch, Germany) installed in a glovebox. The measurements were performed in dynamic flow of argon $\left(30 \mathrm{~mL} \mathrm{~min}^{-1}\right)$, and the heating rate was set to $2^{\circ} \mathrm{C} \mathrm{min}^{-1}$ (open system). A C80 calorimeter (Setaram, France) was used for differential scanning calorimetric (DSC) measurements under static conditions.
The thermodynamic properties of the investigated materials were further investigated by means of a pressure-composition isotherm $(\mathrm{PCl})$ in an automatic Sieverts-type apparatus (Hy-Energy scientific instruments PCT pro-2000). Samples of about $200 \mathrm{Mg}$ were used each time. Initial and ending pressures in the sample chamber for dehydrogenation experiments were 100 and 1 bar. The control precision of the sample temperature was $\pm 0.5^{\circ} \mathrm{C}$. For these experiments the equilibrium state points were acquired each time that the pressure variance $(\Delta P)$ was $<0.1$ bar for $24 \mathrm{~h}$.

The hydrogen desorption and absorption capacities were measured using an automatic Sieverts-type apparatus (Advanced Materials $\mathrm{Co}_{\mathrm{O}}$.). The initial $\mathrm{H}_{2}$ pressures were assigned as $0.01 \mathrm{bar}$ and 60 bar for desorption/absorption, respectively.

\section{Structural Characterization}

The identification of the phases contained in the samples was performed by using a Philips PANalytical X'pert diffractometer with $\mathrm{Cu}_{\mathrm{K \alpha}}$ radiation at $40 \mathrm{kV}$ and $40 \mathrm{~mA}$. XRD patterns were collected in the $2 \theta$ range of $10-80^{\circ}$ with a step increment of $5^{\circ} \mathrm{min}^{-1} . \mathrm{N}-\mathrm{H}$ vibrations in the samples were identified by means of an FTIR spectrometer on a Varian 3100 Unite in DRIFT mode; 32 scans were accumulated, and the scan resolution was $4 \mathrm{~cm}^{-1}$.

\section{Acknowledgements}

The authors acknowledge financial support from the Project of National Science Fund for Distinguished Young Scholars (51225206), the National Natural Science Foundation of China (51472237, 21273229), and the CAS-Helmholtz JRG Project (XMXX201200020861). DESY (Deutsches Elektronen-Synchrtron), Germany, beamline P.02.1. for in situ high-resolution powder X-ray diffraction experiments is also gratefully acknowledged.

\section{Conflict of Interest}

The authors declare no conflict of interest.

Keywords: amides - hydrides $\cdot$ hydrogen storage $\cdot$ kinetics thermodynamics

[1] F. Schüth, B. Bogdanovic, M. Felderhoff, Chem. Commun. 2004, 22492258.

[2] a) T. He, P. Pachfule, H. Wu, Q. Xu, P. Chen, Nat. Rev. Mater. 2016, 1, 16059; b) C. Weidenthaler, M. Felderhoff, Energy Environ. Sci. 2011, 4, $2495-2502$.

[3] a) H. Y. Leng, T. Ichikawa, S. Hino, N. Hanada, S. Isobe, H. Fujii, J. Phys. Chem. B 2004, 108, 8763-8765; b) W. Luo, J. Alloys Compd. 2004, 381, 284-287; c) Z. T. Xiong, G. T. Wu, H. J. Hu, P. Chen, Adv. Mater. 2004, 16, $1522-1525$.

[4] a) L. Ouyang, Z. Cao, H. Wang, R. Hu, M. Zhu, J. Alloys Compd. 2017, 691 , 422-435; b) L. Z. Ouyang, Z. J. Cao, H. Wanga, J. W. Liu, D. L. Sun, Q. A. Zhang, M. Zhu, J. Alloys Compd. 2014, 586, 113-117; c) L. Z. Ouyang, Z. J. Cao, H. Wang, J. W. Liu, D. L. Sun, Q. A. Zhang, M. Zhu, Int. J. Hydrogen Energy 2013, 38, $8881-8887$.

[5] a) J. Wang, P. Chen, H. Pan, Z. Xiong, M. Gao, G. Wu, C. Liang, C. Li, B. Li, J. Wang, ChemSusChem 2013, 6, 2181-2189; b) J. H. Wang, T. Liu, G. T. Wu, W. Li, Y. F. Liu, C. M. Araujo, R. H. Scheicher, A. Blomqvist, R. Ahuja, Z. T. Xiong, P. Yang, M. X. Gao, H. G. Pan, P. Chen, Angew. Chem. Int. Ed. 2009, 48, 5828-5832; Angew. Chem. 2009, 121, 5942-5946. 
[6] J. Yang, A. Sudik, D. J. Siegel, D. Halliday, A. Drews, R. O. Carter 3rd, C. Wolverton, G. J. Lewis, J. W. Sachtler, J. J. Low, S. A. Faheem, D. A. Lesch V. Ozolins, Angew. Chem. Int. Ed. 2008, 47, 882-887; Angew. Chem. 2008, 120, 896-901.

[7] A. Borgschulte, M. O. Jones, E. Callini, B. Probst, S. Kato, A. Zuttel, W. I. F. David, S. Orimo, Energy Environ. Sci. 2012, 5, 6823-6832.

[8] a) M. Aoki, K. Miwa, T. Noritake, G. Kitahara, Y. Nakamori, S. Orimo, S. Towata, Appl. Phys. A 2005, 80, 1409-1412; b) F. E. Pinkerton, G. P. Meisner, M. S. Meyer, M. P. Balogh, M. D. Kundrat, J. Phys. Chem. B 2005, 109 6-8.

[9] J. J. Hu, Y. F. Liu, G. T. Wu, Z. T. Xiong, Y. S. Chua, P. Chen, Chem. Mater. 2008, 20, 4398-4402.

[10] J. J. Hu, M. Fichtner, P. Chen, Chem. Mater. 2008, 20, 7089-7094.

[11] a) B. Li, Y. F. Liu, J. Gu, M. X. Gao, H. G. Pan, Chem. Asian J. 2013, 8, $374-$ 384 ; b) B. Li, Y. F. Liu, J. Gu, Y. J. Gu, M. X. Gao, H. G. Pan, Int. J. Hydrogen Energy 2013, 38, 5030-5038; c) H. G. Pan, S. B. Shi, Y. F. Liu, B. Li, Y. J. Yang, M. X. Gao, Dalton Trans. 2013, 42, 3802-3811.

[12] Z. T. Xiong, J. J. Hu, G. T. Wu, P. Chen, W. F. Luo, K. Gross, J. Wang, J. Alloys Compd. 2005, 398, 235-239.

[13] a) M. U. Niemann, S. S. Srinivasan, A. Kumar, E. K. Stefanakos, D. Y. Goswami, K. McGrath, Int. J. Hydrogen Energy 2009, 34, 8086-8093; b) H. J. Cao, G. T. Wu, Y. Zhang, Z. T. Xiong, J. S. Qiu, P. Chen, J. Mater. Chem. A 2014, 2, 15816-15822.
[14] H. Wang, G. Wu, H. Cao, C. Pistidda, A.-L. Chaudhary, S. Garroni, M. Dornheim, P. Chen, Adv. Energy Mater. 2017, n/a-n/a.

[15] a) L. Z. Ouyang, X. S. Yang, M. Zhu, J. W. Liu, H. W. Dong, D. L. Sun, J. Zou, X. D. Yao, J. Phys. Chem. C 2014, 118, 7808-7820; b) M. Zhu, H. Wang, L. Z. Ouyang, M. Q. Zeng, Int. J. Hydrogen Energy 2006, 31, 251 257.

[16] a) C. Liang, Y. Liu, Y. Jiang, Z. Wei, M. Gao, H. Pan, Q. Wang, Phys. Chem. Chem. Phys. 2011, 13, 314-321; b) N. S. Gamba, P. Arneodo Larochette, F. C. Gennari, RSC Adv. 2015, 5, 68542-68550; c) H. Cao, H. Wang, T. He, G. Wu, Z. Xiong, J. Qiu, P. Chen, RSC Adv. 2014, 4, 32555-32561.

[17] H. Wang, H. J. Cao, G. T. Wu, T. He, P. Chen, Energies 2015, 8, 68986909.

[18] Z. T. Xiong, G. T. Wu, J. J. Hu, P. Chen, W. F. Luo, J. Wang, J. Alloys Compd. 2006, 417, 190-194.

[19] G. Amica, F. Cova, P. Arneodo Larochette, F. C. Gennari, Phys. Chem. Chem. Phys. 2016, 18, 17997-18005.

Manuscript received: February 23, 2017

Revised manuscript received: April 14, 2017

Accepted manuscript online: April 18, 2017

Version of record online: May 31, 2017 